\title{
PENGGUNAAN DOA BATUNA'U \\ DALAM TRADISI ETNIK LIO DI DESA NGALUKOJA KECAMATAN MAUROLE KABUPATEN ENDE: SEBUAH KAJIAN LINGUISTIK KEBUDAYAAN
}

\author{
Idris Mboka \\ Program Pascasarjana Universitas Nusa Cendana, idris.mboka@yahoo.com
}

DOI: 10.17510/ paradigma.v6i2.95

\begin{abstract}
This study aims to identify and describes the verbal symbols and cultural imagery of Lio Ethnic (LE) community which are contained in Batuna'u Prayer (BP). The theory used as analytical scalpel is the Cultural Linguistics Theory (CLT). This study shows 5 forms of BP used in LE community, which are the traditional house construction BP (THC), going to sow BP (GS), delivering dowry BP (DD), going to school BP (GSC), and deceased person BP (DP). From these five forms of BP, there are verbal symbols of a language grammatical discourse (phonology, morphology, and syntax), and the metaphor styles of language, metonymy, poetic sound, and pararelism phrase. After in-depth interpretation of those verbal symbols, some cultural imagery of LE community has been found, such as (1) belief/religion imagery, (2) social imagery, (3) political imagery, (4) human ego towards else imagery, (5) beauty imagery, (6) fear imagery, (7) appreciative imagery, and (8) honor imagery. These study findings describe the noble values which are manifested in Batuna'u prayers. Therefore, they will be beneficial for the Lio Ethnic community in general, and especially for Lio Ethnic students and scholars that have not recognized the noble values contained in Batuna'u prayers.
\end{abstract}

\section{KEYWORDS}

Lio language; Lio ethnic; batuna'u prayer; verbal symbols; imagery; cultural linguistics.

\section{Pendahuluan}

Etnik Lio (disingkat EL) merupakan salah satu etnik yang mendiami wilayah Kabupaten Ende di Pulau Flores, Nusa Tenggara Timur. EL sampai saat ini masih sangat dipengaruhi adat dan budaya. Kebudayaan EL dapat dilihat pada acara adat ataupun acara seremonial biasa. EL lazimnya memberi sesajian kepada alam dan leluhurnya. Kebudayaan masyarakat Lio masih sangat dipengaruhi oleh nilai-nilai kepercayaan yang merupakan simbiosis animisme, dinamisme, dan spiritualisme. Meskipun zaman berubah serta ilmu pengetahuan dan teknologi bertambah maju, EL hingga saat ini masih tetap konsisten mempertahankan adat dan kebudayaannya. Sejalan dengan pandangan itu, Wisu $(2014,16)$ mengatakan bahwa, pada masa 
yang sangat lampau, masyarakat yang tersebar di sepanjang lereng perbukitan itu pernah didatangi berbagai kebudayaan asing dalam rentang waktu yang cukup lama. Namun, berbagai kebudayaan luar itu ternyata tidak mampu membawa perubahan yang berarti pada masyarakat Lio.

Masyarakat Lio pada umumnya bermatapencarian bertani atau berladang yang masih sangat tradisional, hidup berdampingan dengan alam serta menjunjung tinggi norma adat dalam menjalankan kehidupan antara sesama kelompok adat ataupun dengan kelompok adat lain. Berkaitan dengan sistem kepercayaan dan religius dalam konteks kebudayaan seperti yang telah disebutkan di atas, EL mempunyai tradisi tersendiri, seperti upacara adat Nuka Nggua (ritual adat penyambutan musim tanam), Nggua Keti Uta (pesta adat menyambut musim panen), Kema Sao Ria (acara pembangunan rumah adat). Tradisi budaya itu merupakan media untuk mendekatkan diri kepada Dua Gheta Wawo Wulu Wula dan Nggae Wena Tana (kekuatan yang ada di atas lapisan langit dan yang terdalam, wujud tertinggi/Tuhan serta alam. Selain itu, EL juga masih memercayai mitos. Ada beberapa mitos yang masih berkembang saat ini, yakni manusia pertama orang Lio yang disebut Lepe dan Mbusu yang diyakini sebagai Adam dan Hawanya masyarakat EL. Selain itu, mitos Ine Pare (Dewi Padi), Tura Jaji (Perjanjian Adat) yakni perjanjian adat Lio dan Sikka, mitos danau Kelimutu yang diyakini sebagai tempat bersemayan roh orang yang sudah meninggal dan lain sebagainya. Berkaitan dengan mitos itu Eliade dalam Hans Daeng $(2000,16)$ menyatakan bahwa mitos bukan pemikiran intelektual dan bukan pula hasil logika, melainkan semacam orientasi spiritual dan mental untuk berhubungan dengan yang ilahi. Bagi masyarakat arkais tradisional, mitos berarti suatu cerita yang benar dan menjadi milik mereka yang paling berharga karena merupakan sesuatu yang suci, bermakna, menjadi contoh manusia dalam bertindak, memberi makna dan nilai pada kehidupan ini.

Masyarakat Lio masih menganggap manusia yang sudah meninggal berada di sekitar orang hidup, mengetahui tindak-tanduknya, serta menjaga keturunannya yang masih hidup. Kepercayaan itu termanifestasi dalam doa tradisional EL. Salah satunya adalah doa batunau (DB). Doa ini secara langsung meminta kepada leluhur agar senantiasa menjaga dan melindungi orang yang masih hidup serta mengusir hal-hal yang tidak baik.

DB merupakan salah satu unsur yang paling penting dalam kehidupan EL karena berkaitan langsung dengan kepercayaan dan keyakinan. Dalam acara seremonial adat ataupun acara seremonial lain, DB selalu digunakan. DB diungkapkan secara lisan dan bahasa yang digunakan konvensional atau bahasa adat yang berbeda dari bahasa Lio yang digunakan dalam komunikasi sehari-hari.

Ada dua masalah yang dikaji dalam penelitian ini dan diformulasikan dalam bentuk pertanyaan. (1) Simbol verbal apa sajakah yang terdapat dalam DB? (2) Apa imajeri budaya masyarakat etnik Lio yang mendasari simbol verbal $\mathrm{DB}$ ?

\section{Penelitian Terkait, Konsep, dan Teori}

Ada beberapa penelitian linguistik kebudayaan yang menginspirasi penulis ini untuk meneliti. Salah satunya, Erom (2014) yang menulis alasan nama Manggarai dianggap kasar dan nama Katolik dianggap sopan. Tulisan itu mengungkap imajeri budaya orang Manggarai berdasarkan pemberian nama Manggarai dan nama Katolik yang dimaknai sebagai yang kasar dan tidak kasar. Untuk memberikan pemahaman yang lebih mendalam dalam tulisan ini beberapa konsep dibuat yaitu batunau dan bahasa Lio.

Secara semantis batunau adalah doa tradisional dalam kebudayaan EL. DB dapat digunakan di mana saja dan kapan saja sesuai dengan keinginan, baik digunakan sendirian maupun bersama dengan anggota keluarga atau anggota masyarakat. Kenyataan itu sejalan dengan pandangan Paul Arndt SVD yang menyebutkan, sebagai bagian dari sistem religi, EL juga memiliki doa. Doa atau sembahyang yaitu momen 
penciptaan relasi antara manusia dan sang khalik yang dalam masyarakat itu disebut batunau. Batunau itu besifat oral, fungsional, dan kontekstual, sesuai dengan kegiatan sosial budaya berdimensi religius dengan aneka konsep doa pula.

Secara historis komparatif, bahasa Lio di Flores Tengah termasuk kelompok bahasa Melayu Polinesia Sare (2014). Bahasa Lio merupakan salah satu bahasa daerah yang ada di Provinsi Nusa Tenggara Timur, tepatnya di Kabupaten Ende dan sebagian kecil di Kabupaten Sikka. Di Kabupaten Ende, terdapat dua etnik, yakni EL dan Etnik Ende. EL yang menggunakan bahasa Lio (sara Lio), sedangkan etnik Ende menggunakan bahasa Ende (sara Ende). Kedua etnik itu saling memahami walaupun menggunakan bahasa yang berbeda (Sare 2014).

Ada sejumlah pernyataan teoretis Palmer yang berkaitan dengan teori linguistik kebudayaan. Pernyataan teoretis itu akan menjadi dasar untuk mendeskripsikan fitur-fitur linguistis bahasa ritual dan menginterpretasi imajeri budaya masyarakat yang mendasari pembentukan fitur linguistis itu.

Language is the play of verbal symbols that are based in imagery. Imagery is what we see in our minds eye, but it is also the taste of a mango, the feel of walking in a tropical downpour, the music of Mississippi Massala. Our imaginations dwell on experiences obtained through all the sensory modes, and then we talk (Palmer 1996, 3).

MenurutErom (2010), itu merupakan pernyataan teoretis paling utama dalam teori linguistik kebudayaan. Dikatakan demikian karena pernyataan teoretis itu dimulai dari definisi bahasa yang merupakan entitas utama linguistik kebudayaan. Oleh karena itu, teori itu dapat dianggap membawahkan semua pernyataan teoretis lain yang berkaitan dengan teori linguistik pada umumnya, dan teori linguistik kebudayaan khususnya.

Realisasi fisik penggunaan bahasa dan kajian bahasa adalah bunyi, bentuk kata, urutan kata, dan makna kata. Demikian pula halnya dalam masyarakat penutur bahasa. Secara teknis linguistik, bunyi bahasa dikaji dalam bidang fonologi, bentuk kata bahasa dikaji dalam bidang morfologi, susunan kata-kata bahasa dikaji dalam bidang sintaksis, dan makna bahasa dikaji dalam bidang semantik. Keempat bidang linguistik itu merupakan aspek gramatikal bahasa (Fromkin 2013, 61-277).

Simbol verbal, sebuah istilah yang digunakan oleh Palmer, merupakan realisasi fisik bahasa dalam pergaulan masyarakat bahasa. Dengan demikian, simbol verbal dapat dianggap mengacu ke aspek gramatikal, yang menurut Fromkin (2013, 61-277) mencakup morfologi, sintaksis, semantik, fonetik, dan fonologi. Selain itu, simbol verbal juga mengacu ke gaya bahasa yang mencakup metafora, metonimi dan bunyi puitis, dan skenario wacana yang mencakup wacana, narasi, legenda, dongeng, dan lain-lain. Mungkin istilah simbol verbal yang digunakan Palmer sama dengan istilah bentuk dalam tulisan sejumlah peneliti yang menekuni linguistik kebudayaan selama ini.

Imajeri adalah apa yang kita lihat dalam mata pikiran kita (Palmer 1996, 3). Imajeri adalah representasi mental yang bermula sebagai analogi konseptual dari pengalaman perseptual langsung organ pancaindra (Palmer 1996, 47). Organ pancaindra meliputi mata, telinga, hidung, lidah, dan kulit. Berkaitan dengan itu, dikenal istilah berbagai macam imajeri: visual, auditori, kinestetik, olfaktori, dan temperatur (Palmer 1996, 46).

Pikiran manusia mengidentifikasi semua hal yang ditangkap atau dirasakan oleh organ pancaindra. Semua yang ada di dunia yang dilihat oleh mata, didengar oleh telinga, dicium oleh hidung, dikecap oleh lidah, dan dirasakan oleh kulit direkam di dalam pikiran. Kelima indra itu dapat memperkaya imajeri para penutur suatu bahasa yang mendasari semua permainan simbol verbal bahasa. 
Tampilan fisik yang lengkap dan bekerja dalam pancaindra menentukan kekayaan kuantitas dan kualitas imajeri seseorang. Dengan demikian, imajeri seseorang akan lebih kurang daripada imajeri lainnya jika dia kekurangan jenis dan jumlah satu pancaindra sekalipun. Orang buta akan kekurangan imajeri indah, cantik, dan ganteng, atau banyak objek fisik lain yang ada di dunia. Orang tuli akan kekurangan imajeri suara merdu manusia atau suara burung. Orang yang penciumannya tidak normal akan kekurangan imajeri rasa bau, rasa amis, atau rasa tengik benda di dunia. Orang yang lidahnya tidak bekerja normal akan kekurangan imajeri rasa manis, rasa pahit, atau rasa asam benda di dunia. Orang yang kulitnya tidak peka akan kekurangan imajeri rasa kasar, rasa halus, atau rasa lembut benda di dunia.

Pernyataan teoretis lain berkaitan dengan cakupan bidang penerapan Linguistik Kebudayaan. Tentang cakupan bidang penerapannya dapat dilihat dalam pernyataan teoretis berikut ini.

This theme of imagery in language provides a basis for examining a surprisingly wide range of linguistics topics. It applies not only to narrative and figurative language, but also to the semantics of words and grammatical constructions, to discourse, and even to phonology. In the past, these linguistic domains have been subjected to a disparate and mutually inconsistent theories as though they differ in kind, when they really only represent different points of view. They can be best understood in terms of a single theory of culturally defined mental imagery - a cultural theory of linguistic meaning. In this cultural linguistics, phonemes are heard as verbal image arranged in complex categories, words acquire meanings that are relative to image - schemas, scenes and scenarios; clauses are image-base constructions; discourse emerges as a process governed by the reflexive imagery of itself; and worldview subsumes it all. The approach builds on older traditions as well as contemporary theories in anthropological linguistics but it draws most heavily on new developments in cognitive linguistics, the most rapidly growing branch of linguistics.

Pernyataan teoretis tersebut menegaskan bahwa teori linguistik kebudayaan dapat diterapkan atau digunakan sebagai pedoman dalam menganalisis semua fitur linguistis yang disebut simbol verbal bahasa oleh Palmer (1996, 3), baik aspek gramatikal, seperti fonologi, morfologi, sintaksis, semantik, maupun gaya bahasa yang mencakup metafora, metonimi dan bunyi puitis, serta skenario wacana yang mencakup wacana, narasi, legenda, dongeng, dan lain-lain.

\section{Metodologi Penelitian}

Penelitian linguistik kebudayaan menganalisis bahasa yang ada pada suatu kebudayaan tertentu. Dalam mengkaji bahasa dan kebudayaan EL, penulis ini menggunakan teks WDB yang sudah diterjemahkan ke dalam bahasa Indonesia. Dalam melaksanakan penelitiannya, peneliti ini menggunakan metode deskriptif kualitatif. Metode ini digunakan untuk menganalisis data deskriptif, yaitu dengan cara memaparkan, mengkaji, dan mendeskripsikan simbol verbal atau fitur linguistis serta menginterpretasi imajeri budaya pada tiap-tiap fitur linguistis yang mendasari ciptaan Doa Batunau.

\section{Hasil Penelitian dan Pembahasan}

Berdasarkan hasil penelitian, terdapat lima bentuk doa batunau sebagai berikut.

\section{Teks (1) Doa Batunau DB Mengerjakan Rumah Adat (MRA).}

O.... Dua gheta lulu wula nggae wena tana. Gha mo nai sao ria, moo tika tenda bewa, mo benu sao loa tenda, mo benu sao kita mo susu pu. Loa tenda tau nama nala, mo tau susu nggua nama bapu. Gha aku mo welu watu tau maro manu, aku loka semi tau mbei wawi. Na mera mo 
keta ndii moo gha. Buru we mae puu we paka mae boge. Ata polo mae kabe, ana wera mo rete mona. Ria mo tau dari nia bewa tau pase lae.

\section{Teks (2) DB wau mbana tedho (Pergi Menanam PM) pada Masyarakat EL.}

Tana watu dua bapu, kami mea nosi mo mbana tedho, miu mulu kami ndu, miu dheko kami jejo, kami mbana leka tana nawalo, leta leka watu o molo. We kami tedo tembu wesa wela, kobe mae ngoe, leja mae kanga, pare no keo bhoka watu woa tembu tana watu woga, mo poto boo, mo renggi bahanda.

\section{Teks (3) DB Tu Jala Ata Fai (Mengantarkan Belis MB)}

O.... Dua gheta lulu wula nggae wena tana, gha aku mo poto manusia do gha one, mo nai sao tika tenda, mo kolo mae ro ote mae node. Mo tau benu one loa tenda, mo tau nu gha buu, banga gha waja, jila gha lika, gha kami mo mbana tu jala ngawu ana loo, pasa geti ata fai mo nai gha sao tika gha tenda, peti mae pati panggo mae pera, mbana leka jala o masa, leta leka wolo o molo, mae pera tanda , mae sagesa, mae sidi so ae mae wia.

\section{Teks (4) DB Mbana Sekolah Pergi Sekolah (PS)}

O... Mamo Wula, Mbale, Weni, Tasya, Wisu, Isa, Sea, Mboka, Lele, Beke, Ligoloba. Aku pai miu mai aku niu miu sea, mai sawe sea bhaka mai dowa sea sawe mai ka bou mai pesa bela, ka are pesa nake, gha wasia ana mamo miu Hidin moo mbana sekolah lau kupang. Miu mbana sama miu lora bela no ana mamo miu. So nggengge tipo pama, tipo ngere nio, pama ngere kasa, tipo mae talo pama mae mona. Nggia ngai kai sia ngere leja siga rade ndara ke we ngere wula ja, sariwu laru liwu kabe-kabe talo sangasu mula watu rate-rate mona. Hidin menga beke sariwu kee, Hidin menga bheja sangasu kanggo.

\section{Teks (5) Penggunaan Doa Batunau DB Ata Mata/ Batu Ju (Orang MeninggalOM) \\ O.... Ahmad Tema kau mata mutu gu, ree ia pai, mata kau ndua dowa ia, ghawa leka leke o ser, tenga leka o leda ghawa, leka sao saga boko, kau walo-sai no ola-ola ghawa leka konde no bobi, aku mo joka wola sumba walo,kau mbana no mase no leja mena, bere no ae lau, ta kau mbana ghawa tiwu kau mae niku, ghawa mutu baru duu, wola se no ola-ola do-lau ghawa leka mesi meta, fata bata ngaga.}

\subsection{Analisis Skenario Wacana DB}

Skenario wacana menyatukan berbagai jenis skema yang mencakup (1) partisipasi, (2) tindak tutur, (3) urutan, (4) perspektif, dan (5) ideasi. Setelah mendalami kelima teks WDB dijelaskan beberapa hal berikut yang terkait dengan cakupan skenario wacana itu.

\subsubsection{Wacana DB mengerjakan Rumah Adat (MRA)}

Dalam mengerjakan rumah adat, yang menuturkan DB adalah mosalaki puu (ketua adat) tuturan itu diungkapkan secara monolog di hadapan para partisipan yang merupakan sesama manusia. Namun, partisipan yang mendengarkan hal itu hanya diam karena doa itu ditujukan secara langsung kepada dua gheta wawo lulu wula nggae wena tanah (wujud tertinggi) diyakini dalam imajeri masyarakat EL sebagai Tuhan yang mampu memberikan pertolongan, kekuatan serta petunjuk kepada manusia untuk mengerjakan rumah adat. Dalam hal ini EL menganggap dengan tenaga manusia saja tidak cukup untuk membangun sebuah rumah adat sehingga itu diharapkan kepada Tuhan untuk memberikan kekuatan berupa fisik, mental, dan semangat agar mampu menyelesaikan tugasnya. Selain itu, penutur DB MRA juga mengharapkan 
dengan dibangunnya rumah adat itu dapat membawa kemakmuran dan kedamaian dapat diraih bagi seluruh masyarakat adat setempat.

\subsubsection{Wacana DB Pergi menanam (PM)}

Tuturan WDB PM ini dilakukan oleh orang-orang yang tahu serta fasih dalam melafalkanya, tuturan itu dikomunikasikan secara monolog kepada tana watu (alam), dua bapu (leluhur), serta keluarga. Tuturan ini bermaksud meminta izin kepada tanah watu (alam) yang merupakan tempat untuk bercocok tanam. Bagi EL alamlah yang memberikan hidup terhadap manusia. Dalam tuturan itu selain meminta izin kepada alam, penutur juga meminta izin kepada leluhur dalam imajeri masyarakat EL leluhur merupakan nenek moyang atau orang tua yang telah meninggal serta mewariskan tanah watu (alam, ladang untuk bercocok tanam) kepada keturunanya yang masih hidup, selain itu, leluhur juga mempunyai peran dalam hal ini menjaga keturunannya yang masih hidup.

Dalam tuturan ini kamunikasi juga dilakukan oleh penutur kepada sesama manusia dalam hal ini yang menjadi partisipan adalah anggota keluarga (dalam rumah). Bentuk ungkapan wau-se (segeralah turun) merupakan bentuk komunikasi dengan keluarga sekaligus menunjukkan imajeri keseriusan dalam bekerja.

\subsubsection{Wacana DB Mengantarkan belis (MB)}

Tuturan wacana DB MB ini dituturkan oleh manusia dalam hal ini orang yang dipilih oleh keluarga untuk melakukan DB. Ditujukan kepada dua gheta lulu wula nggae wena tanah (penguasa alam) sebagai pemilik tunggal atas apa-apa yang hidup serta yang mati. Dituturkan secara monolog di hadapan para partisipan dalam hal ini keluarga dan kerabat yang telah bersiap-siap untuk mengantarkan belis. Partisipan dalam DB MB tidak memiliki peran apa-apa kecuali mendengarkan apa yang dituturkan oleh penutur itu.

Bentuk pemanggilan itu bukan hanya untuk meminta atau memohon melainkan pemberitahuan kepada Tuhan sebagai pemilik manusia yang hidup laki-laki maupun perempuan. Dalam hal ini, manusia (penutur) memberitahukan bahwa dari pihak laki-laki akan mengantarkan belis kepada pihak perempuan. Berkaitan dengan kepercayaan penutur juga meyakini Tuhanlah yang menjaga/melindungi dalam proses pengataran belis, pernikahan maupun dalam menjalankan rumah tangga nantinya. Dalam kebudayaan EL, pernikahan merupakan amanat dari Tuhan serta para leluhur agar mendapat anak atau keturunan yang banyak serta membawa manfaat bagi semua orang.

\subsubsection{Wacana DB Pergi Sekolah (PS)}

DB pergi sekolah dituturkan oleh keluarga bapak, kakak, paman atau orang dewasa yang mampu DB. DB itu ditujukan kepada leluhur yang namanya tercantum pada baris pertama DB itu. Diungkapkan secara monolog dihadapan partisipan yaikni keluarga dari orang yang akan pergi sekolah. Dalam hal ini masyarakat EL meyakini bahwa leluhur walaupun secara kasat mata tidak dapat melihat, tetapi mereka mampu melihat menjaga bahkan makan bersama-sama dengan keturunannya. Penutur dalam hal ini manusia yang hidup meminta kepada leluhur untuk menjaga, melindungi, serta memberikan kepintaran kepada manusia yang dalam hal ini anak cucu mereka yang akan pergi sekolah. 


\subsubsection{Wacana DB Orang Meninggal OM}

Tuturan DB OM itu dilakukan oleh keluarga yang fasih menuturkan DB ditujukan kepada orang yang baru meninggal Ahmad Thema (Alm). Doa itu diungkapkan secara monolog. Yang menjadi partisipan adalah keluarga yang masih hidup. Menggunakan kalimat perintah sebagai bentuk penolakan serta menyuruh orang yang telah meninggal untuk pergi walo se kau no ola-ola (pergi sudah kamu ke alam sana [Kelimutu]). Yang meninggal dianggap sebagai hal yang sial dalam imajeri EL. Oleh karena itu dalam imajeri EL orang yang meninggal harus diperlakukan secara baik dengan memberikan makanan pati ka ata mata berupa nasi dan daging yang nantinya akan menjadi bekal arwah itu dalam perjalanan dari kuburanya ke danau Kelimutu. Selain itu, dikuburkan serta didoakan secara baik (Doa adat maupun doa dalam ajaran agama modern) agar yang meninggal itu tidak durubai (memberi kutukan) berupa sakit bahkan kematian kepada orang yang masih hidup (keluarganya).

\subsection{Analisis aspek Gramatika Fonologi}

Fonologi multidimensional. Teori ini digunakan untuk menganalisis nada turun naik berbagai bahasa ritual yang kaya akan ekspresi metaforis. Fonologi budaya tidak jauh berbeda dengan fonologi autosegmental dalam linguistik. Oleh karena itu, untuk menganalisisnya penulis menggunakan istilah fonologi autosegmental. Fonologi autosegmental mengacu kepada suatu fakta arus tuturan memiliki tingkatan dan dimensi berbeda. Perbedaan itu terletak pada tekanan stress dan nada pich. Unsur tekanan berkaitan dengan keras lembutnya bunyi bahasa dan nada berkaitan dengan tinggi rendahnya bunyi bahasa seperti yang terdapat dalam DB MRA, DB MB, DB PS, dan DB OM. Dari keempat bentuk DB itu hanya dibahas tiga bentuk karena DB MRA dan DB MB berdasarkan struktur kalimatnya mempunyai makna gramatika yang sama. Perhatikan contoh berikut.

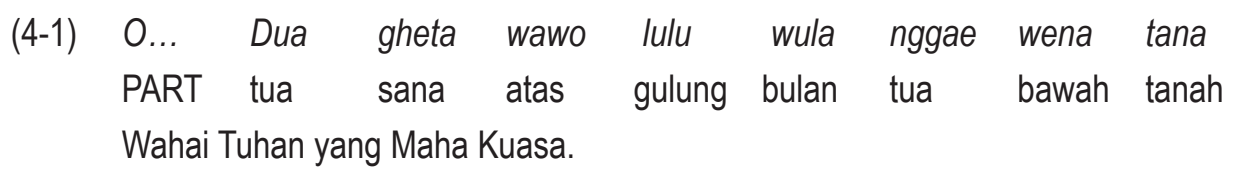

Contoh (4-1) di atas bunyi autosegmental ditandai dengan bunyi vokal $0 . .$. yang terdapat pada awal kalimat. Bunyi O... dituturkan dengan suara sedikit keras kemudian bunyi selanjutnya yakni kata Dua gheta wawo lulu wula nggae wena itu dituturkan dengan menggunakan nada datar dan lembut dengan ekspresi sungguh-sungguh serta penuh harapan. Itu dapat diasumsikan sebagai bentuk pemanggilan Tuhan oleh penutur DB MRA. Pemanggilan itu berkaitan dengan sistem religi atau kepercayaan masyarakat EL bahwa Tuhan lebih tinggi dari pada manusia.

(4-2) O... mamo Wula, Mbale, Weni, Tasya, Wisu, Isa, Sea, Mboka, Lele, Beke, Ligoloba PART nenek Wula, Mbale, Weni, Tasya, Wisu, Isa, Sea, Mboka, Lele, Beke, Ligoloba Wahai leluhurku Wula, Mbale, Weni, Tasya, Wisu, Isa, Sea, Mboka, Lele, Beke, Ligoloba.

Pada contoh data (4-2) tidak jauh berbeda dengan contoh terdahulu, bunyi vokal O... diucapkan dengan suara agak sedikit keras selanjutnya kata mamo Wula, Mbale, Weni, Tasya, Wisu, Isa, Sea, Mboka, Lele, Beke, Ligoloba menggunakan nada datar. Nama-nama itu merupakan leluhur dari keluarga atau keturunan anak yang akan pergi sekolah diucapkan oleh penutur. Bunyi vokal $0 .$. itu secara gramatikal mengandungi makna pemanggilan Leluhur yang namanya disebut pada contoh itu. Itu merupakan imajeri 
kepercayaan EL bahwa leluhur berada di tempat yang tinggi atau sama dengan Tuhan seperti pada contoh terdahulu.
(4-3) O... Ahmad Thema
PART Ahmad Thema
Wahai Ahmad Thema

Pada Contoh (4-3) di atas terdapat bunyi vokal (O...) pada awal kalimat diucapkan dengan nada sedikit keras dengan ekspresi kesedihan serta penuh harapan pula kepada (orang yang baru meninggal). Bunyi vokal 0 ... dalam hal ini mempunyai makna gramatikal pemanggilan almarhum itu agar mendengarkan apa yang diucapkan oleh penutur DB. Dalam kepercayaan masyarakat EL, orang yang baru meninggal tidak jauh berbeda dengan leluhur yang sudah lama meninggal ia masih dekat dan mampu mendengarkan apa yang dibicarakan manusia, bahkan roh almarhum itu dapat melihat, mendengar, serta mengutuk atau durubai kepada orang yang masih hidup ketika tidak diperlakukan dengan baik dalam acara pemakaman, dan lain sebagainya. Hal itu menandakan bahwa orang yang baru meninggal juga dianggap sudah berada di posisi yang tinggi berbeda dengan manusia yang masih hidup di dunia.

\subsection{Morfologi}

Dalam linguistik kebudayaan, proses morfologis seperti afiksasi, reduplikasi, dan komposisi dipandang sebagai bentuk-bentuk yang didorong oleh imajeri budaya guyub tutur tertentu. Dari kelima bentuk DB di atas tidak ditemukan proses morfologi afiksasi melainkan hanya klitiksasi dan reduplikasi. Hal itu bisah dipahami karena bahasa Lio merupakan bahasa isolatif sehingga sangat jarang ditemukan proses morfologis berupa afiksasi. Pembahasan mengenai klitiksasi dan reduplikasi dianggap perlu mengingat keduanya merupakan sedikit dari fenomena linguistis budaya yang didorong oleh imajeri guyub tutur dalam hal ini guyub tutur EL. Berikut ini merupakan contoh proses morfologis itu.

\section{(4-4) Wau-se kita moo mbana tedho turun-KLIT kita PREP jalan tanam}

Segeralah turun kita akan pergi menanam.

Pada kata wau-se terdapat n-klitik -se yang melekat pada bentuk dasar wau (turun) yang merupakan kelas kata verba kehadiran n-klitik -se itu mempunyai kontribusi atau mempengaruhi makna dasar sehingga secara gramatikal kata itu mempunya makna 'segeralah turun'. Hal itu menunjukkan keseriusan penutur untuk bekerja.

$$
\begin{aligned}
& \text { (4-5) mae pera tanda, mae sage-sa, mae sidi-so, ae mae wia } \\
& \text { jangan tunjuk tanda, jangan celaka-KLIT, Jangan antuk-KLIT air jangan menyebar } \\
& \text { Jangan berikan tanda-tanda. }
\end{aligned}
$$

Pada contoh (4-5), klausa itu terdiri dari empat frasa. Setiap frasa memiliki makna gramatikal yang berbeda, frasa mae pera tanda (jangan tunjukkan tanda), mae sage-sa mempunyai makna gramatikal (jangan celaka), kehadiran Klitik -sa sebagai penegasan untuk berhati-hati. Pada frasa mae sidi-so (jangan terantuk kehadiran klitik -so merupakan penegasan lanjutan yang mempunyai tingkatan lebih spesifik yang secara gramatikal mengandungi makna kecelakan yang tidak disengaja dilakukan oleh kaki (terantuk). Dalam 
kepercayaan guyub tutur EL terantuk dalam konteks acara dalam hal ini mengantarkan belis merupakan pertanda sesuatu hal yang tidak baik yang akan terjadi pada kedua orang yang akan menikah ataupun keluarga mereka.

(4-6) sariwu laru liwu kabe-kabe talo sangasu mula watu rathe-rathe mona
seribu batang liwud menghalangi tidak bisa, seratus tanam batu tekan terlepas Seribu orang tidak bisa menghalangi, seratus orang tidak bisa menekan.

Pada kutipan itu terdapat dua buah reduplikasi penuh yaitu kabe-kabe dari kata dasar kabe yang mempunyai arti 'halang' (dihalangi) dan rathe-rathe dari kata dasar rathe 'sering menekan'. Reduplikasi itu menunjukkan cara seseorang atau kelompok untuk menghalangi orang lain atau menggagalkan usaha orang lain.

\subsection{Sintaksis}

Pembahasan mengenai struktur sintaktis sangat penting dalam linguistik kebudayaan karena berkaitan langsung dengan cara pandang manusia, dalam hal ini cara pandang EL terhadap entitas yang ada. Secara umum bentuk bahasa yang digunakan dari kelima DB itu paralelisme yang terdiri dari SP, SPO dan SPOK. Namun, secara umum pola sintaktis yang terdapat dari kelima DB itu, yakni S,P dan O, sesuai dengan pola umum sintaktis yang digunakan oleh EL untuk berkomunikasi setiap hari. Berikut ini contoh pola sintaktis kelima DB itu.

(4-7) aku loka semi // tau kanda wawi,
1 TG tumpah semi

Saya menumpahkan semin untuk membuat kandang babi.

(4-8) aku pai miu mai // aku пiu miu sea $1 \mathrm{TG}$ panggil $2 \mathrm{JMK}$ datang $1 \mathrm{TG}$ pesan $2 \mathrm{JMK}$ hadiri

Saya memanggil kalian datang.

Pada contoh (4-7) kata aku (saya) mengisi fungsi subjek, loka (menumpahkan) mengisi fungsi predikat, dan semi mengisi fungsi objek. Kata aku berkategori nomina, loka berkategori verba, dan semin berkategori nomina $(\mathrm{N}+\mathrm{V}+\mathrm{N})$.

Pada contoh (4-8) kata aku (saya) mengisi fungsi subjek, kata pai (memanggil) mengisi fungsi predikat dan kata miu mai mengisi fungsi objek. Kata aku berkategori nomina, pai berkategori verba, dan miu mai mengisi fungsi nomina $(\mathrm{N}+\mathrm{V}+\mathrm{N})$.

Dalam berkomunikasi, EL menunjukkan kesamaan dengan beberapa contoh data di atas, seperti percakapan dalam bekerja kau kema apa eja? (kamu mengerjakan apa, Saudara)? aku kema kopo wawi, atau menanyakan orang makan kau ka sawe ta lae? (kamu sudah makan belum)?

Beberapa uraian di atas dapat disimpulkan bahwa secara tipologis, susunan kata pada uraian data di atas memiliki pola SVO. Hal ini menunjukan subjek berkategori nomina (manusia) dianggap sangat penting dalam suatu kegiatan atau aktivitas yang dilakukan. 


\subsection{Analisis Simbol Verba Gaya Bahasa}

Analisis simbol verbal gaya bahasa mencakup metafora, metonimi, bunyi puitis, dan ungkapan paralelisme.

\subsubsection{Metafora}

Metafora yang dibahas dalam pokok pembahasan ini merujuk pada metafora yang ditawarkan oleh Lakoff yang dimodifikasi oleh Palmer sehingga metafora ini menjadi satu kesatuan yang tidak dapat dipisahkan dari TLK, yaitu metafora struktural, metafora orientasional, metafora ontologis, dan metonim. Berikut ini beberapa metafora yang telah diklasifikasikan menjadi tiga kelompok.

\subsubsection{Metafora Struktural.}

Metafora struktural bersifat kompleks, memiliki pemetaan sistematis dari suatu konsep ke konsep lain seperti yang terdapat pada contoh (4-9)-(4-12) berikut ini.
(4-9) gha aku mo welu watu tau maro manu
di sini 1 TG mau taruh batu buat kandang ayam
saat ini saya akan menaruh batu untuk mengerjakan kandang ayam
(4-10) aku mo loka semi tau mbei wawi
1 TG mau tumpah semin buat kandang babi
saya akan menaruh semin untuk buat kandang babi

Contoh (4-11 dan 4-12) di atas merupakan metafora struktural. Tampak bahwa kata wawi (babi) dan manu (ayam), dalam hal ini struktur tubuh manusia diletakkan pada struktur ayam dan babi. Selanjutnya, frasa maro manu (kandang ayam) dan mbei wawi (kandang babi) diletakkan pada struktur rumah adat yang dimiliki oleh manusia.
(4-11) Kau mata mutu gu, ree ia pai, 2 TG mati Kelimutu panggil, rusak la (gunung) panggil Kamu meninggal karena dipanggil Kelimutu dan gunung la.

Pada Contoh (4-11) secara harfiah makna dari kata itu adalah kamu meninggal dipanggil danau Kelimutu, rusak karena dipanggil gunung la. Memanggil merupakan ontologi manusia yang dipadankan dengan danau Kelimutu dan gunung la seolah-olah gunung bisa memanggil. Kata gunung dalam hal ini menggambarkan tanah sehingga orang yang meninggal dianggap telah dipanggil tanah untuk kembali ke asalnya (tanah). Frasa itu berkaitan dengan frasa mata kau ndua dowa ia (meninggal kamu sudah turun dari la) menggambarkan bahwa orang yang meninggal akan dikuburkan di bawah gunung la (di dalam tanah) tempat kita berpijak.

$\begin{array}{lllllllll}\text { (4-12) Pasa geti } & \text { ata fai } & \text { mo nai gha sao tika gha tenda, } \\ & \text { tembak beli } & \text { orang perempuan PREP naik disini rumah duduk di sini balai, }\end{array}$ pergi mengantarkan belis perempuan untuk menikah 
Contoh (4-12) di atas merupakan metafora struktural frasa pasa geti ata fai (pergi membeli perempuan). Dalam hal ini belis dipadankan dengan uang yang bisa membeli manusia. Frasa ini terkesan kasar di telinga pendengar (peneliti ini). Pada hemat peneliti ini, masih ada kata lain yang lebih halus seperti mbana tu jala ngawu (mengantarkan belis).

\subsubsection{Metafora Orientasional}

Metafora orientasional terbentuk berdasarkan pada pengalaman fisik dan budaya, dan memberi konsep orientasi tempat atau ruang, seperti contoh berikut ini.

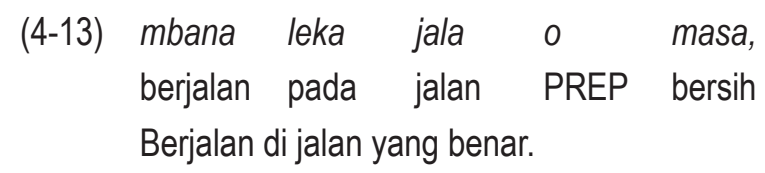

Contoh (4-13) di atas menunjukkan metafora orientasional yang ditunjukkan oleh kata masa (bersih) yang merupakan metafora untuk menyatakan kebenaran. Dalam hal ini kebenaran merupakan dasar dari semua tindakan atau perbuatan yang dilakukan.

\subsubsection{Metafora Ontologis}

Metafora ontologis menyamakan aktivitas, emosi, dan pikiran dengan entitas seperti yang terdapat pada contoh berikut ini.

$$
\begin{array}{lllllll}
\text { (4-14) na mera mo keta ndii moo } & \text { gha } \\
\text { ini duduk mau dingin tubuh mau } & \text { segar } \\
\text { Agar yang tinggal selalu sehat. } & & &
\end{array}
$$

Pada contoh (4-14), kata keta dan gha merupakan sinonim yang mengandungi makna kesejukan. Dalam hal ini penutur mengonsepkan suatu entitas untuk menjelaskan kondisi entitas lain yang bersifat abstrak, hanya dirasakan oleh indra perasa dalam hal ini kulit. Kulitlah yang merasakan dingin dan segar.

\subsubsection{Metonimi}

Kata metonimi diturunkan dari kata Yunani meta yang berarti menunjukkan perubahan dan onoma yang berarti nama. Dengan demikian, metonimi adalah suatu gaya bahasa yang menggunakan sebuah kata untuk menyatakan hal lain, yang mempunyai pertalian yang sangat dekat. Hubungan itu dapat berupa penemu untuk hasil penemuan, pemilik untuk barang yang dimiliki, akibat untuk sebab, sebab untuk akibat, isi untuk menyatakan kulitnya. Metonimi tampak pada contoh berikut ini.

$$
\begin{array}{lllll}
\text { (4-15) mo benu sao loa tenda } \\
\text { mau penuh rumah meluap tenda }
\end{array}
$$

Agar memenuhi rumah dan tenda.

Pada contoh (4-15) di atas, kata loa (meluap) merupakan metonimi untuk menyatakan banyaknya/ keramaian yang ditimbulkan oleh keturunan yang banyak. 


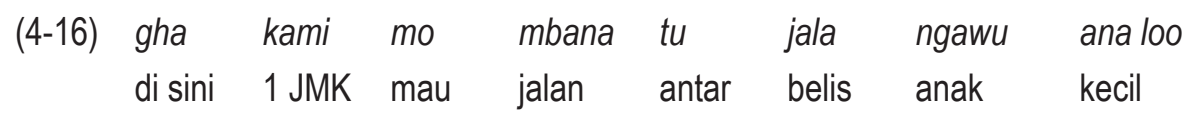
Saat ini kami akan mengantar kan belis anak kita.

Pada contoh (4-16), kata ngawu (barang) merupakn metonimi yang merujuk pada keseluruhan barang yang dibawa seperti hewan, emas, uang, tempat tidur yang digunakan sebagai belis dari pihak laki-laki untuk diantar ke pihak perempuan.

\subsection{Bunyi Puitis}

Beberapa contoh berikut ini hanyalah abstraksi yang diambil dari beberapa contoh data dari kelima DB itu. Hal itu perlu dilakukan untuk mencari tahu bunyi puitis yang dikemas penutur dalam tuturan doa itu.

Bunyi puitis yang akan dianalisis mencakup aliterasi dan asonansi. Aliterasi merupakan pengulangan bunyi konsonan yang sama dalam baris-baris puisi, biasanya pada awal kata/perkataan yang berurutan. Pengulangan seperti itu menimbulkan kesan keindahan seperti berikut ini.

(4-17) gha aku mo welu watu tau maro $\underline{\text { manu, }}$ disini 1 TG mau lepas batu buat kandang ayam

Saya menaruh batu untuk mengerjakan rumah ayam.

(4-18) so nggengge tipo pama, tipo ngere nio, pama ngere kasa PART halang keliling jaga keliling seperti kelapa jaga seperti pagar Menjaga dan membelanya

(4-19) tipo mae talo pama mae mona keliling jangan kalah jaga jangan terlepas menjaganya selalu

(4-20) sariwu laru liwu kabe-kabe talo sangasu mula watu rate-rate mona seribu batang liwut halang-halang tidakbisa seratus tanam batu tekan-tekan lepas Ratusan hingga ribuan orang tidak bisa menghalang

Pada contoh (4-17) terdapat aliterasi bunyi /we/ dan /wa/ pada kata welu dan watu, bunyi /ma/ dan /a/ pada kata maro dan manu. Pada contoh (4-18) bunyi /po/ dan /pa/ pada kata tipo dan pama. Bunyi /po/ dan /lo/ pada kata tipo dan talo pada contoh (4-19). Adapun pada contoh (4-20), bunyi /wu/ dan /wu/ pada kata sariwu dan liwu, bunyi /sa/ dan /wa/ pada kata sangasu dan watu.

Asonansi merupakan pengulangan bunyi vokal yang sama pada kata/perkataan yang berurutan dalam baris-baris puisi. Pengulangan seperti itu menimbulkan kesan kehalusan, kelembutan, kemerduan atau keindahan bunyi. Kedua bunyi puitis itu akan tampak pada data dan tiap-tiap petikan yang memiliki bunyi asonansi yang diberi garis bawah seperti pada contoh berikut ini.

(4-21) gha mo nai sa $\underline{\text { sian, moo tika tenda bewa }}$

di sini mau naik rumah besar mau duduk tenda besar

Di sini kami mau masuk dan duduk di rumah adat. 
Pada contoh (4-21) asonansi terjadi pada awal kata seperti bunyi /sa/ dan /ri/ pada kata sao dan ria, sedangkan asonansi pada akhir kata seperti bunyi /ka/ dan /ge/ yang tedapat pada kata paka dan boge.

(4-22) buru-we mae puu paka mae boge

buruk-KLIT jangan pohon tubuh jangan bagian

Yang buruk jangan datang sehingga tidak ada yang mati.

Pada contoh (4-22) asonansi terjadi pada awal kata seperti bunyi /bu/ dan /pu/ pada kata buru dan puu. Adapun asonansi pada akhir kata seperti bunyi /da/ dan /wa/ pada kata paka dan boge.
(4-23) aku pai miu mai aku niu miu sea
$1 \mathrm{TG}$ panggil $1 \mathrm{JMK}$ datang $1 \mathrm{TG}$ pesan kalian hadir
Saya memanggil kalian datang semuanya.

Pada contoh (4-23), asonansi terjadi pada awal kata seperti bunyi /pa/ dan /ma/ pada kata pai dan mai. Pada contoh ini tidak terdapat bunyi asonansi pada akhir kata.

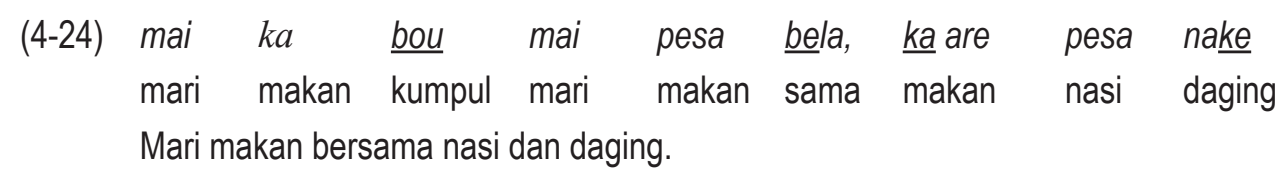

Pada contoh (4-24), asonansi terjadi pada awal kata seperti bunyi /bo/ dan /be/ pada kata bou dan bela. Adapun bunyi asonansi pada akhir kata yaitu bunyi /ka/ dan /ke/ pada kata ka dan nake.
(4-25) mo tau nu gha buu, banga gha waja, jila gha lika, mau buat asap di sini tungku, menyala di sini tungku menyala disini tungku Untuk memasak di dapur

Pada contoh (4-25), asonansi terjadi pada awal kata seperti bunyi /ba/ dan /wa/ yang terdapat pada kata banga dan waja, sedangkan bunyi asonansi yang terdapat pada akhir kata seperti bunyi /la/ dan /ka/ pada kata jila dan lika.

Berdasarkan identifikasi bunyi, asonansi dan aliterasi ditemukan pada setiap contoh. Dengan demikian, dapat dikatakan tuturan DB mengandungi nilai estetik/keindahan. Bunyi-bunyi yang indah dapat dipandang sebagai suatu cara untuk merayu (Tuhan/Leluhur) sehingga mengabulkan permintaan atau permohonan dalam imajeri penutur.

\subsection{Ungkapan Paralelisme}

Paralelisme ialah gaya bahasa yang berusaha menyejajarkan pemakaian kata-kata atau frase-frase yang menduduki fungsi sama dan memiliki bentuk gramatikal sama. Paralelisme adalah pengungkapan dengan kata, frasa, atau klausa yang sejajar. Pengulangan kata untuk menegaskan hal yang terdapat dalam puisi. Kata yang diulang pada awal kalimat dinamakan anafora, dan yang diakhir kalimat dinamakan evipora.

Dalam data terdapat beberapa contoh bentuk paralelisme seperti berikut ini. 
$\begin{array}{llllllll}\text { (4-26) dua } & \text { gheta wawo lulu wula // nggae wena tana } \\ \text { tua ke sana atas gulungan bulan } & \text { tua bawah tanah }\end{array}$

Tuhan yang berada di atas langit di bawah tanah

Ungkapan paralelisme pada contoh (4-26) di atas kata dua (laki-laki) yang berada di atas gulungan langit dan Nggae (tua perempuan) yang berada di bawah dasar tanah. Kata du'a (Tua laki-laki) dan Nggae, (tua perempuan). Kedua orang tua ini diasosiasikan dengan alam laki-laki menguasai langit dan perempuan yang menguasai tanah. Kedua kekuatan ini menyatu menjadi suatu kekuatan besar yang diyakini EL sebagai wujud tertinggi/ Tuhan.

$\begin{array}{lllll}\text { (4-27) buru mae puu } / / & \text { paka mae boge } \\ \text { penyakit jangan pohon } & \text { jelek jangan bagian } \\ \text { Penyakitjangan menyerang tubuh, sehingga tidak ada kematian. }\end{array}$

Pada cuplikan (4-27), bentuk paralelisme itu terdapat pada kata buru (penyakit) dan paka (jelek) mengungkapkan masaalah kesehatan, penyakit, atau sakit merupakan masalah dalam imajeri EL: penyakit/ sakit dapat menyebabkan orang meninggal. Oleh karena itu, untuk membangun rumah hendaknya didoakan secara baik, agar rumah itu tidak menjadi petaka bagi penghuninya.

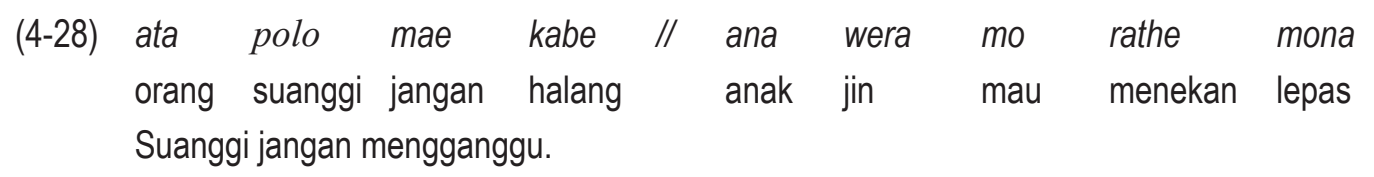

Ungkapan paralelisme pada contoh (4-28) di atas yang secara semantis mempunyai makna, yang berbeda ata polo, merujuk ke orang (suanggi), sedangkan ana wera merujuk ke kekuatan yang dimiliknya (jin atau makhluk yang dapat diperdayakan oleh orang suanggi). Suanggi merupakan momok yang paling ditakuti oleh EL karena dianggap sebagai penghalang atau perusak.

$\begin{array}{llllll}\text { (4-29) mo poto bo'o // } & \text { mo renggi bhanda } \\ \text { mau angkat kenyang } & \text { mau angkat kekayaan }\end{array}$

Meningkatkan pendapatan untuk meraih kekayaan.

Ungkapan paralelisme pada contoh (4-29) kata bo'o (kenyang) dan bhanda (kaya) merupakan orientasi manusia dalam bekerja yakni untuk mendapat makanan untuk bertahan hidup serta pendapatan yang lebih banyak untuk meraih kekayaan.

$\begin{array}{lllllll}\text { (4-30) banga gha waja // jila } & \text { gha lika, } \\ \text { menyala di sini tungku } & \text { menyala di sini } & \text { tungku } \\ & \text { Menyalakan api di tungku. }\end{array}$

Ungkapan paralelisme pada cuplikan (4-30) banga gha waja// jila gha lika memiliki makna yang sama untuk menyatakan perempuan untuk memasak di dapur. Kata banga (menyala) dan jila (menyala) kedua sinonim itu merujuk ke api yang dinyalakan di dapur. Dalam hal ini, dapur atau tempat masak diidentikkan 
dengan pekerjaan perempuan dalam imajeri EL. Oleh karena itu, perempuan yang dilamar untuk dijadikan istri itu diharapkan bahwa kelak memasak atau menyediakan makanan untuk suami dan anak-anaknya.

$$
\begin{aligned}
& \text { (4-31) mai ka bou // } \text { mai pesa bela, ka a re } / / \text { pesa nake, } \\
& \text { mari makan kumpul // mari makan bersama makan nasi // kunyah daging } \\
& \text { Mari makan nasi dan daging bersama-sama. }
\end{aligned}
$$

Ungkapan paralelisme pada contoh (4-31) menunjukkan kebersamaan antara manusia yang masih hidup dan leluhurnya. Frasa mai ka bau // mai pesa bela, merupakan bentuk ajakan untuk makan bersama, sedangan frasa ka are // pesa nake merupakan hidangan ayang telah disiapkan untuk disantap bersamasama, baik orang yang hidup maupun leluhur.

$$
\begin{array}{lllllll}
\text { (4-32) tipo mae talo } & \text { mama mae mona, } \\
\text { menjaga jangan kala } & \text { merangkul jangan } & \text { lepas } \\
\text { Leluhur selalu menyertainya } & & & &
\end{array}
$$

Ungkapan paralelisme pada contoh (4-32) menunjukkan harapan guyub tutur masyarakat EL kepada leluhur untuk menjaga keturunannya. Kata tipo (menjaga) pama (merangkul) dalam hal ini, masyarakat EL meyakini bahwa leluhur akan menjaga keturunannya yang sedang mengikuti pendidikan di tanah orang.

$$
\begin{aligned}
& \text { (4-33) ghawa leka leke o sere// tenga leka o leda ghawa } \\
& \text { di sana pada tiang yang tancap/l balok pada PREP memanjang disana } \\
& \text { di sana rumah kamu kuburan }
\end{aligned}
$$

Ungkapan paralelisme pada contoh (4-33) di atas, kata leke (tiang) dan tenga (balok) merupakan bentuk kuburan persegi panjang yang dibuat dengan kayu, bagian dalamnya terdiri dari tiang yang ditancapkan dan balok yang dibuat memanjang. Jika orangnya sudah dimasukkan ke dalam liang lahat, tubuhnya ditutupi dengan papan, baru selanjutnya ditutup dengan tanah.

$$
\begin{array}{lllllll}
\text { (4-34) } & \text { aku } & \text { mo joka } & \text { wola // } & \text { sambu walo } \\
& 1 \text { TG } & \text { mau } & \text { tolak } & \text { pulang // } & \text { sambut lagi }
\end{array}
$$

Saya menyuruhmu pergi akan menyambut yang baru.

Ungkapan paralelisme pada contoh (4-34), kata joka (tolak) dan sambu (menyambut) merupakan antonim. Bentuk itu menyampaikan kepada orang yang meninggal bahwa keluarga sudah menolak atau menyuruhnya (alm.) pergi dan akan menerima hal yang baru (baik).

$$
\begin{aligned}
& \text { (4-35) kobe mae ngoe // leja mae kanga } \\
& \text { malam jangan mengais // siang jangan kering } \\
& \text { hama jangan merusaknya }
\end{aligned}
$$

Kata ngoe (mengais) dan kanga (kering) pada ungkapan paralelisme itu merujuk ke hama dan alam (matahari panas). Hama dan matahari panas/ kemarau berkepanjangan menyebabkan rasa takut akan musibah kelaparan karena diserang oleh hama ataupun musim kemarau panjang. 


$\begin{array}{llllllll}\text { (4-36) mo kolo mae } & \text { ro } & / / & \text { ote } & \text { mae node } \\ \text { mau kepada jangan sakit } / / & \text { otak } & \text { jangan buntu } \\ \text { Agar pikiran tidak terganggu } & & & & & \end{array}$

Contoh (4-36) kata kolo (kepala) dan ote (otak). Dalam hal ini, EL memandang bahwa manusia dewasa harus menikah agar tidak menjadi beban pikiran.

\subsection{Imajeri Budaya}

1. Imajeri budaya $E L$ yang tercermin dalam wacana $D B M R A$, yaitu $E L$ menganggap untuk mengerjakan rumah adat dengan menggunakan tenaga manusia saja tidak cukup, kecuali ada campur tangan dari Tuhan dan Leluhur. Hal itu merupakan imajeri keyakinan (religi) yang dianut oleh masyarakat etnik Lio dalam menjalankan kehidupan sosial dan budaya. Selain itu, EL juga menganggap bahwa dengan pembangunan rumah adat itu masyarakat akan terhindar dari penyakit serta marabahaya lain, serta mendapat hasil panen atau kemakmuran bagi seluruh masyarakat adat yang ada di kampung adat Ngalukoja.

2. Imajeri budaya dalam wacana DB PM. Dalam DB PM mengandungi imajeri yaitu masyarakt EL memandang bahwa ada entitas lain selain Tuhan yakni tana watu (alam) dan dua bapu (leluhur). Kedua entitas ini merupakan faktor penting dalam kehidupan EL: tanah memberikan kehidupan terhadap manusia, sedangkan leluhur menikmati alam (tanah) serta mewariskan tanah kepada keturunannya. Atas dasar keyakinan itu, sebelum mulai menanam, EL meminta izin kepada tanah dan leluhur itu.

3. Dalam tuturan ini tana watu diucapkan terlebih dahulu. Dapat dipahami bahwa manusia yang hidup bergantung pada alam khususnya masyarakat agraris Lio yang hidup bergantung pada tanah sebagai sumber pendapatan. Leluhur ditempatkan pada urutan kedua oleh penutur dengan alasan imajeri yakni leluhur juga menggunakan tanah demi mendapat penghasilan untuk menghidupi keturunannya.

4. Imajeri budaya yang tercermin dalam DB MB yakni EL menganggap manusia sebagai ciptaan Tuhan. Oleh karena itu, untuk dinikahkan perlu diberitahukan kepada-NYA sebagai pemilik tunggal atas yang hidup. Selain itu, EL memandang bahwa setiap pekerjaan mempunyai risiko yang langsung dirasakan melalui tanda-tanda. Belis mengandungi imajeri penghargaan yang diberikan dari pihak laki-laki kepada pihak perempuan. Selain itu, belis juga dapat mengangkat derajat seorang (lelaki). Kepercayaan itu sesuai dengan kebudayaan EL yang memperlakukan secara berbeda laki-laki yang menikah dengan memberikan belis atau sebaliknya lelaki hanya menikah saja tidak memberikan apa-apa kepada pihak perempuan.

5. Imajeri budaya yang tercermin dalam wacana DB PS. EL menganggap dengan sekolah akan mengubah nasib seseorang. Oleh karena itu, berhati-hati serta mendoakan agar Tuhan dan Leluhur menjaga orang itu merupakan hal yang harus diutamakan demi meraih kesuksesan yang akan membawa nama besar keluarga ataupun leluhur.

6. Imajeri budaya EL yang tercermin dalam DB OM. EL menganggap orang yang meninggal adalah sial sehingga diperlakukan secara baik agar tidak terjadi hal-hal yang tidak diinginkan pada keluarga di kemudian hari. Perlakuan itu dapat diperinci sebagai berikut. Pertama, memberikan makanan atau pati 
ka ata mata mengandungi imajeri makanan sebagai bekal dalam perjalanan arwah. Kedua, diberikan pakaian yang bagus yang dipercayai akan ia pakai menuju ke Kelimutu. Yang ketiga, hewan ternak yang dipotong di saat kematian juga diyakini oleh EL bahwa hewan itu akan dibawa pula oleh arwah orang meninggal itu ke Kelimutu. EL meyakini arwah orang yang telah meninggal akan berkumpul di Kelimutu, di sana arwah itu hidup layaknya manusia di dunia: makan, minum, bercocok tanam, berkeluarga, dan sebagainya.

7. Imajeri budaya yang terkandung dalam simbol verbal fonologi pada DB MRA dan DB MB secara umum sama. Bentuk tuturan dengan nada vokal $0 .$. datar yang berada pada awal kalimat baris pertama dan sebelah kanannya terdapat klausa dua gheta wawo lulu wula nggae wena tana, bisa diasumsikan bahwa bunyi vokal $\mathrm{O}$... itu secara semantis mempunyai makna pemanggilan sosok tertinggi, yakni dua gheta I ulu wula nggae wena tana yang berada di atas yang derajatnya lebih tinggi dari manusia. Sama halnya dengan bunyi vokal O... yang terdapat pada kalimat pertama WDB PS dan WDB OM, WDB PS bentuk pemanggilan leluhur yang namanya disebutkan satu per satu. Hal itu menunjukkan EL menganggap leluhur juga sama dengan Tuhan, berada di tempat yang lebih tinggi dan mampu memberikan pertolongan kepada manusia yang masih hidup. Begitupun dengan bentuk pemanggilan orang yang baru meninggal, EL meyakini bahwa ruh orang itu sudah pergi ke asalnya sehingga orang yang baru meninggal dapat disebut leluhur. Oleh karena itu, vokal $O$ yang terdapat dalam DB OM samadengan WDB PS. Dengan demikian, imajeri budaya yang tercermin dalam bentuk fonologi kedua WDB itu, yaitu EL menganggap leluhur dan orang yang sudah meninggal berada di tempat yang lebih tinggi.

8. Pada contoh tuturan (4-4) - (4-6) wau-se, merupakan bentuk perintah untuk melakukan pekerjaan. klitik -se dalam kata itu mengandungi imajeri keseriusan dalam bercocok tanam. Klitik -sa dan -so pada frasa mae sage-sa (jangan celaka) dan mae sidi-so (jangan terantuk) mengandungi imajeri ketakutan sebagaiman telah dijelaskan bahwa kedua hal itu merupakan pertanda yang tidak baik dalam konteks ini bagi orang yang akan menikah ataupun keluarganya. Selain itu, bentuk reduplikasi kabekabe (menghalangi) dan rathe-rathe (menekan) merupakan cara untuk menghalangi orang lain. Bentuk reduplikasi itu mengandungi imajeri ketakutan akan sesama manusia, sebagaimana EL menganggap bahwa tidak semua orang menyukai apa yang dibuat dan apa yang diperoleh sesamanya.

9. Pada contoh (4-7) - (4-8) pola umum sintaktis dalam bahasa Lio yang terdapat dalam DB, yakni SVO $(\mathrm{S}+\mathrm{V}+\mathrm{O})$. Interelasi antara pola sintaktis dan kebudayaan EL memperlihatkan imajeri egoisme manusia dengan menempatkan subjek manusia selalu di sebelah kiri verba dan objek.

10. Tuturan pada contoh (4-10) aku mo loka semi tau kopo wawi berhubungan dengan kalimat 8 , gha aku mo welu watu tau maro manu. Keduanya merupakan metafora yang bermakna gramatikal sama (saya akan menaruh batu/semin untuk mengerjakan kandang ayam/babi). Metafora kandang di sini sebenarnya untuk mengungkapkan rumah adat, sedangkan manusia dimetaforakan dengan ayam dan babi.

Pada dasarnya ayam dan babi merupakan hewan ternak yang paling dekat dengan manusia serta sangat mudah dipelihara. Perkembangbiakan kedua hewan itu sangat cepat. Babi sekali beranak dapat mencapai puluhan ekor. Begitupun ayam, telur menetas dapat menghasilkan puluhan ekor anak ayam. Untuk menjaga babi dan ayam itu agar tidak hilang atau dimakan binatang, orang Lio membuat kandang. Dalam masyarakat guyub tutur EL, kandang babi disebut kopo, sedangkan kandang ayam disebut kasa. Kedua metafora itu menggambarkan manusia yang berada dalam satu daerah kekuasaan kopo/kasa. Istilah lain dari kopo kasa dalam EL dapat juga merujuk ke hukum dan tata cara yang berlaku. Adapun 
rumah adat yang dimetaforakan dengan kandang babi dan ayam merupakan simbol keberadaan seorang mosalaki. Kehadiran rumah adat berarti pengakuan baik dari dalam maupun luar masyarakat kopo kasa Ngalukoja.

11. Pada contoh kalimat (4-11) Kau mata mutu gu, ree la pai, secara harfiah maknanya kamu yang meninggal dipanggil danau (Kelimutu). Orang Lio meyakini bahwa roh orang yang telah meninggal akan pergi ke Kelimutu. Danau Kelimutu terdiri atas tiga kawah yang disebut tiwu ata polo, (kawah tempat berdiamnya para arwah suanggi), tiwu ata bupu (kawah tempat berdiamnya roh para orang tua, dan tiwu nuwamuri jemu) (kawah tempat berdiamnya para roh pemuda dan pemudi). Imajeri itu berasal dari mitos dan hal-hal gaib yang dirasakan oleh EL itu sendiri. Hal-hal gaib itu tersimpan di dalam benak sehingga menimbulkan imaji kepercayaan itu.

12. Dalam bentuk tuturan mata mutu gu // ree ia pai, terdapat kata-kata yang bersinonim gu (teriak) dan pai (memanggil) tetapi maknanya tidak sepenuhnya sama. Kata gu mempunyai makna gramatikal memanggil dengan suara yang keras dan orang yang dipanggil itu tidak kelihatan, sedangkan kata pai menggunakan suara yang pelan karena orang yang dipanggil dapat dilihat langsung dari jarak dekat. Jika dikaitkan dengan konteks, kata gu dimotivasi oleh imajeri jauh, yaitu Kelimutu yang memang jauh dari guyub tutur EL khususnya yang ada di Ngalukoja. Sementara itu, kata pai yang disatukan dengan kata la (gunung) yang merupakan metafora untuk daratan (tanah), maka kata pai itu didorong oleh imajeri kedekatan dalam hal ini tanah yang selalu diinjak di mana pun manusia berada.

13. Tuturan pada contoh (4-12) Pasa geti ata fai, makna metafora itu adalah pergi membeli (geti) perempuan. Secara pragmatis frasa itu mengungkapkan saat akan berpergian untuk mengantarkan belis kepada perempuan. Kata geti (membeli) yang dimetaforakan dari kata belis wurumana, muncul karena didorong oleh imajeri belis banyak/besar yang diantarkan oleh pihak laki-laki ke pihak perempuan. Cara itu sesuai dengan kebudayaan EL, artinya seorang laki-laki yang akan menikah hendaknya menyediakan belis. Belis dalam kebudayaan EL dapat berupaka emas, kerbau, sapi, kuda, kambing ayam, dan uang.

14. Tuturan pada contoh (4-13) mbana leka jala o masa secara semantis mempunyai makna berjalan di jalan yang benar. Secara pragmatis makna ungkapan itu merujuk ke pernikahan yang dianggap sebagai perbuatan baik/benar yang diajarkan oleh Tuhan/Leluhur yang harus diikuti oleh keturunannya. Imajeri EL berkaitan dengan tuturan itu, yakni menganggap bahwa menikah dapat memberikan ketenangan lahir batin. Bagi orang yang akan menikah hal itu dibuktikan dengan ungkapan kolo mae ro, ote mae node yang artinya dengan menikah dapat memberikan ketenangan baik kepada laki-laki maupun perempuan.

15. Pada contoh (4-14) kata keta dan gha merupakan orientasi manusia untuk mendapat kenyamanan. Kenyamanan merupakan imajeri manusia yang didorong oleh rasa aman tentram, terhindar dari penyakit serta hal lain yang dapat menghambat pekerjaan orang yang ada di dalam rumah.

16. Tuturan pada contoh (4-15) mo benu sao loa tenda (mau memenuhi rumah dan tenda). Kata loa (meluap) di sini untuk menyatakan banyak/ramai. Orang Lio meyakini bahwa dengan menikah akan mendapat keturunan banyak sehingga dapat menghidupkan rumah, artinya memberikan keramaian di rumah itu. Imajeri EL mengenai tuturan itu adalah menikah merupakan cara untuk mendapat keturunan. 
17. Tuturan pada contoh (4-16) gha kami mo mbana tu jala ngawu ana loo (di sini kami mau mengantarkan belis untuk anak-anak), kata ngawu (barang), dimetonimikan dengan ngawu (barang), yang merujuk ke semua barang yang dibawa, seperti hewan, emas, dan tempat tidur yang digunakan sebagai belis. Hal itu didorong oleh imajeri EL yang sangat malu jika apa yang diberikan selalu disebut-sebut.

18. Secara sederhana imajeri yang terkandung dalam bunyi puitis adalah imajeri keindahan. Imajeri itu muncul berdasarkan dorongan hati dan perasaan penutur agar apa yang diminta dan diharapkan mendapat restu serta dikabulkan baik dari Tuhan maupun Leluhur seperti dalam tuturan pada contoh (4-17)-(4-25).

19. Tuturan pada contoh (4-26) Dua gheta wawo Iulu wula, Nggae ghale wena tana merupakan dua bentuk kalimat paralel yang mempunyai makna yang tua (laki-laki) berada di atas gulungan bulan dan perempuan tua yang berada di bawah dasar tanah. Kedua klausa itu mempunyai makna yang sama untuk menyatakan kekuatan antara langit dan bumi yang diyakini oleh masyarakat. Dua nggae sebagai wujud tertinggi (Tuhan) dipercayai oleh EL telah ada sebelum segala sesuatu ada. Dua hadir sebagai yang sulung, yang paling awal hadir dari segalanya termasuk manusia. Dua bahkan telah ada sebelum bumi tercipta. Kata Dua selalu berarti, (sulung), (terdahulu), (tertua), (berdaulat), (berpribadi tertinggi). Adapun konsep Nggae mengandungi makna (keagungan), penuh dengan daya, kebijaksanaan, kekuatan, kekayaan.

20. Tuturan pada contoh (4-27), buru we mae puu, we paka mae boge mempunyai makna jangan terkena penyakit dan tubuh jangan rusak (mati). Puu merupakan batang pohon yang diartikan sebagai tubuh manusia, sedangkan boge merupakan bagian tubuh manusia (isi/daging). Imajeri yang mendasari simbol verbal itu yakni masyarakat tutur BL menganggap tubuh sebagai pusat serangan penyakit. Penyakit dapat mengakibatkan orang mati yang diungkapkan dengan kata boge. Kata boge dalam BL dimaknai sebagai daging/bagian tubuh yang dipotong. Yang dipotong itu biasa dikatakan ree (jelek) yang menyatakan orang mati. Dengan demikian, muncul kalimat dalam berkomunikasi, seperti anake ree lewa, (anaknya telah meninggal), demi o ree mbana soo beu (kalau yang jelek pergi jauh). Ungkapan itu disesuaikan dengan konteks orang mati.

21. Tuturan pada contoh (4-28), ata polo mae kabel/ ana wera mo rathe mona. Kata atapolo (suanggi) dan anawera (jin yang dipercayai suanggi). Menurut kepercayaan EL, suanggi dibedakan menjadi dua, yaitu ata polo mbanda (orang yang memiliki ilmu baik serta membantu orang sakit, seperti dukun) dan ata polo koo (orang yang memiliki ilmu sihir karena faktor ekonomi dan suka mengganggu ketenangan orang serta tidak segan-segan menghabisi orang yang dibencinya dengan menyuruh anawera (jin). Oleh karena, itu suanggi ata koo merupakan momok yang paling ditakuti dalam imajeri EL.

22. Tuturan pada contoh (4-29), Mo poto boo// mo renggi bhanda. Tuturan paralelisme itu bermakna sesuatu yang diinginkan dicapai/diraih oleh EL, yaitu mendapat hasil yang baik serta meningkatkan kondisi ekonomis. Mendapat hasil yang baik menjadi dambaan bagi semua orang, demikian juga EL yang agraris. Hasil pertanian yang didapat diharapkan mampu menghidupi keluarga dan selebihnya dapat disimpan ataupun dijual untuk membeli kebutuhan lain, dan jika masih ada lebihnya, untuk ditabung. Imajeri EL menganggap bahwa dengan bekerja orang dapat hidup sejahtera. Hal yang paling utama dalam kehidupan adalah kebutuhan makan dan minum, sedangkan kekayaan tercapai jika ada penghasilan lebih.

23. Tuturan pada contoh (4-30), mo banga gha wajall jila gha lika. Ungkapan paralelisme itu bermakna bahwa memasak adalah pekerjaan perempuan. Imajeri guyub tutur EL yang terkandung dalam ungkapan itu 
adalah bagi orang Lio tugas utama perempuan adalah memasak. Anggapan itu sesuai dengan budaya EL yang patrilinial serta memperlakukan perempuan sebagai kaum yang lemah.

24. Tuturan pada contoh (4-31) adalah imajeri keyakinan EL kepada Leluhur. Sekalipun wujudnya sudah tidak ada, leluhur diyakini makan bersama serta mampu menjaga keturunannya yang masih hidup.

25. Pada contoh (4-32), adalah tuturan Tipo mae talo/l pama mae mona. Kata tipo dan pama mempunyai makna menjaga. Dalam hal ini, EL meyakini bahwa leluhur mampu menjaga keturunannya di mana pun mereka berada. Selain itu, EL meyakini bahwa hidup dan mati seseorang bergantung pada leluhur.

26. Imajeri EL mengenai tuturan (4-33) ghawa leka leke o sere // tenga leka o leda ghawa merujuk ke liang kubur yang dibuat bentuk persegi dengan menggunakan tiang kayu balok atau usuk untuk menahan tanah dari atas. Kuburan dipandang sebagai rumah orang yang telah meninggal. Dalam hal ini, penutur DB OM itu menyuruh atau mendoakan agar orang yang telah meninggal itu, tinggal di rumahnya, yaitu kuburan.

27. Pada contoh tuturan (4-34), aku mo joka wola // sambu walo mempunyai makna saya menolak kamu yang buruk (mati) dan mau menyambut hal yang baru (baik). Imajeri yang mendasari simbol verbal itu adalah memperlihatkan orang mati dianggap sebagai hal yang buruk/sial dalam guyub tutur EL. Oleh karena itu, hal yang sial itu harus didoakan serta dikuburkan secara baik agar tidak terkena durubai (kutukan), sakit ataupun kematian. Selain itu, orang Lio juga menganggap bahwa setelah selesai keburukan, akan datang kebaikan. Itu tercermin dalam frasa sambu wola (menyambut hal yang baru) baik itu mendapat rezeki anak/cucu maupun rezeki lain.

28. Tuturan (4-35) kobe mae ngoe, leja mae kanga, (malam hama jangan merusaknya siang matahari jangan mengeringkannya). Dalam hal ini Ngoe (mengais) merupakan perilaku entitas binatang yang dimetaforakan dengan malam, sedangkan kanga (kering) dimetaforakan dengan matahari. Keduanya merupakan imajeri ketakutan dalam guyub tutur EL. Orang Lio menganggap bahwa hal yang buruk dapat terjadi pada tanaman, siang ataupun malam. Pada malam hari, hama, seperti ayam hutan, babi hutan, dan tupai akan merusak tanaman. Sebaliknya, siang identik dengan matahari. Matahari yang panas serta curah hujan yang rendah menjadi ancaman bagi para petani yakni dapat mengurangi hasil panen bahkan gagal panen. Ungkapan itu merupakan doa yang ditujukan kepada tanah watu/leluhur untuk menjaga tanaman mereka. Itu didorong oleh imajeri rasa takut akan musibah kelaparan.

29. Tuturan (4-36) mo kolo mae ro ote mae node secara gramatikal mempunyai makna agar tidak menjadi pikiran. Kolo (kepala) dan ote (otak) merupakan tempat menyimpan semua perasaan, atau pikiran yang dapat menimbulkan stres pada orang dewasa. Kutipan itu mengandungi imajeri ketakutan tidak mendapat pendamping hidup ataupun keturunan. Manfaat pendamping hidup sangat banyak, bukan hanya hubungan biologis melainkan juga hal lain, seperti perempuan membantu suami bekerja, menyediakan makanan. Selain itu, mendapat keturunan merupakan orientasi EL yang lazim diungkapkan dengan katakata tau dari nia pase lae (sebagai generasi penerus) atau menggantikan orang tuanya kelak. 


\subsection{Simpulan Imajeri Budaya}

Imajeri merupakan akumulasi dari semua imajeri budaya yang terkandung dalam berbagai simbol verbal di atas.

1. Imajeri Kepercayaan/Keyakinan.

Imajeri ini berkaitan dengan tindakan religius yang dilakukan oleh masyarakat adat Ngalukoja seperti melakukan DB, acara ritual seremonial adat ataupun seremonial biasa, serta memercayai hal gaib, seperti Tuhan, leluhur, dan mitos.

\section{Imajeri Sosial}

Imajeri sosial merupakan sikap dan perasaan yang diterima secara luas oleh masyarakat dan merupakan dasar untuk merumuskan apa yang benar dan apa yang penting.

3. Imajeri politik

Imajeri politik berkaitan dengan cara suatu kelompok adat mempertahankan eksistensinya sebagai kelompok yang mendiri dengan tata cara yang berlaku.

4. Imajeri Keseriusan

Imajeri keseriusan berkaitan dengan karakteristik seseorang atau kelompok dalam melakukan suatu usaha atau bekerja dengan sungguh-sungguh demi keberhasilan.

5. Imajeri Egoisme

Pola umum sintaktis dalam bahasa Lio yang terdapat dalam DB yakni SVO $(S+V+O)$. Interelasi antara pola sintaktis dengan kebudayaan EL memperlihatkan imajeri egoisme manusia. Egoisme itu direalisasikan dalam simbol verbal.

6. Imajeri Keindahan

Imajeri keindahan berkaitan dengan tuturan yang direalisasikan dalam bentuk puitis. Dalam hal ini, tuturan itu menggunakan asonansi dan aliterasi sebagai bentuk rayuan kepada wujud yang tinggi untuk mengabulkan permintaan atau permohonan.

8. Imajeri Rasa Takut

Imajeri rasa takut berawal dari pengalaman yang dirasakan oleh orang lain ataupun diri sendiri, berkaitan dengan sesutau yang mengerikan, seperti kelaparan, kematian, dan rasa sakit.

9. Imajeri Penghargaan

Imajeri penghargaan ditunjukkan dengan pemberian belis dari pihak laki-laki ke pihak keluarga perempuan.

10. Imajeri Penghormatan

Imajeri penghormatan ditunjukkan dengan pemberian sesajian kepada tana watu, dua duabapu no ata mata alam, dan leluhur.

\section{Kesimpulan}

Analisis data menemukan lima bentuk DB dalam EL, yakni DB MRA, DB PM, DB MB, DB PS, dan DB OM. Dalam kelima bentuk DB itu, terdapat simbol verbal wacana, garamatika bahasa (fonologi, morfologi, dan 
sintaksis). Gaya bahasa metafora, metonimi, bunyi puitis dan ungkapan paralelisme. Imajeri EL yang tercermin dalam kelima wacana DB merepresentasikan praktik budaya yang dipertahankan sejak zaman dahulu hingga sekarang yang direalisasikan dalam bentuk simbol verbal, yakni (1) imajeri keyakinan/kepercayaan berupa keyakinan atas eksistensi Tuhan dan leluhur yang dianggap mampu memberikan petunjuk atau sesuatu yang diminta oleh penutur; (2) imajeri sosial berkaitan dengan hubungan antara sesama manusia; (3) imajeri politis berkaitan dengan cara kelompok atau individu mempertahankan eksistensi serta keutuhan dalam kehidupan; (5) pola umum sintaktis dalam bahasa Lio yang terdapat dalam DB yakni $S V O(S+V+O)$. Interelasi antara pola sintaktis dan kebudayaan EL memperlihatkan imajeri egoisme manusia. Egoisme itu direalisasikan dalam simbol verbal; (6) imajeri keindahan berkaitan dengan cara individu atau kelompok menggunakan diksi atau bunyi (aliterasi dan asonansi); (7) imajeri rasa takut berawal dari pengalaman orang lain ataupun diri sendiri, berkaitan dengan sesuatu yang mengerikan; (8) imajeri penghargaan ditunjukkan dengan pemberian belis dari pihak laki-laki ke pihak keluarga perempuan; (9) imajeri penghormatan ditunjukkan dengan pemberian sesajian kepada tana watu, dua duabapu no ata mata (alam, dan leluhur).

\section{Daftar Referensi}

Ahmadi, Muksin. 1990. Keterampilan Berbahasa dan Apresiasi Sastra. Malang: Yayasan Asi Asu Malang, IKIP Malang.

Bloomfield, Leonard. 1933. Foundations of Sociolinguistics. Philadelphia: University of Pennsylvania Press. Chaer, Abdul. 2007. Linguistik Umum. Jakarta: PT Rineka Cipta.

Colletta, J. Nat dan Umar Kayam. 1987. Kebudayaan dan Pembangunan, Sebuah Pendekatan terhadap Antropologi Terapan di Indonesia. Jakarta: Yayasan Obor Indonesia.

Comrie, Bernard. 1989. Language Universals and Linguistik Typology. Edisi ke-2. Oxford: Basil Blackwell.

Daeng J. Hans. 2000. Manusia Kebudayaan dan Lingkungan. Yogyakarta: Pustaka Pelajar.

Dedrick, Don. 1998. Naming the Rainbow: Colour Language, Colour Science, and Culture. Dordrecht: Kluwer. Erom, Kletus. 2010. Sistem Pemarkahan Nomina Bahasa Manggarai dan Interelasinya dengan Sistem Penamaan Entitas: Sebuah Kajian Linguistik Kebudayaan. Disertasi, Universitas Udayana. 2014a. Imajeri Budaya Masyarakat Manggarai (Alasan Nama Manggarai Dianggap Kasar dan Nama Katolik Dianggap Sopan). Kupang Optimisme, Jurnal Bahasa, Sastra dan Budaya [Mei]: 1. 2014b." Penggunaan Nama Samaran (NS) Pada Masyarakat Manggarai (MM)" dalam

Perspektif Teori Linguistik Kebudayaan. Bianglala Linguistika, Jurnal Linguistik 01, no. 02 [Januari]. Liliweri, Alo. 2014. Pengantar Studi Kebudayaan. Bandung: Penerbit Nusa Media. Palmer, F.R. 1990. Semantics. Edisi ke-2. Cambridge: Cambridge University Press.

Palmer, Gary B. 1996. Toward a Theory of Cultural Linguistics. Texas: The University of Texas Press. 2015. Pengantar Teori Linguistik Kebudayaan. Diterjemahkan oleh Kletus Erom. Kupang: Universitas Nusa Cendana.

Sare, A. Angelina. 2014. "Klausa Transitif Bahasa Lio". Bianglala, Jurnal Linguistik 01, no. 2: 61.

Wisu, Wahyudin. 2014. Makna Upacara Adat "Nuka Nggua" pada Masyarakat Lio dalam Persiapan Musim Tanam di Desa Detukeli Dusun Aedari Kecamatan Detukeli Kabupaten Ende. Skripsi, Univrsitas Muhammadiyah Kupang. 